\title{
Intracellular distribution of lead in the liver and kidney of the rat
}

\author{
N. CASTELLINO AND S. ALOJ \\ Institute of Industrial Medicine and Institute of General Pathology, University of Naples, \\ Naples, Italy
}

\begin{abstract}
Castellino, N., and Aloj, S. (1969). Brit. J. industr. Med., 26, 139-143. Intracellular distribution of lead in the liver and kidney of the rat. The distribution of lead in intracellular fractions of liver and kidney has been studied in rats for nine days after intravenous injection of $100 \mu \mathrm{g}$. of lead $\left({ }^{210} \mathrm{~Pb}\right)$ per rat. The radioactivity and the protein nitrogen have been measured in the homogenates and in the nuclei, mitochondria, microsomes, and cell sap. Lead penetrates the cells quickly, being present in all fractions one hour after injection. During the first $\mathbf{7 2}$ hours the relative amounts of lead in the different fractions varied, which ruled out the possibility that all the differences could be explained by redistribution after homogenization. The distribution of the metal within the cell probably depends upon differences in the nature and the stability of bonding to intracellular structures. The binding of lead within the mitochondria seemed to be particularly stable, only $24.4 \%$ of the radioactivity being removed by washing with $0.25 \mathrm{M}$ sucrose or $0.001 \mathrm{M}$ ethylenediaminetetra-acetate or $0.001 \mathrm{M}$ diethylenetriaminopenta-acetate in $0.25 \mathrm{M}$ sucrose. This finding is discussed in relation to haem biosynthesis within the mitochondrion.
\end{abstract}

Previous work on the kinetics of distribution of lead in the rat indicated that the metal diffuses into the extravascular space and penetrates the cells, where it is probably fixed as an organic complex (Castellino and Aloj, 1964). Analysis of the data obtained in rats treated with a chelating agent, ethylene-diaminetetraacetate, confirms the above hypothesis, since different rates of removal of ${ }^{210} \mathrm{~Pb}$ from the tissues have been observed (Castellino and Aloj, 1965). These results are in agreement with the findings of Bolanowska, Piotrowski, and Trojanowska (1964), who described the complex kinetics of lead in rats injected with a single dose of lead labelled with ${ }^{210} \mathrm{~Pb}$ in terms of three compartments with different exchange rates.

Miani and Viterbo (1958) studied the distribution of lead in tissues of the dog by histo-autoradiographic techniques. They reported that the metal is located in various intracellular structures.

Since one of the most important biological effects of lead is its interference with haem biosynthesis, probably due to inhibition of cytoplasmic and mitochondrial enzymes (Goldberg, Ashenbrucker, Cartwright, and Wintrobe, 1956; Rubino, 1961; Rimington, 1951; Eriksen, 1955; Dresel and Falk, 1956; Gajdos and Gajdos-Török, 1958; Bernard, Gajdos, and Gajdos-Török, 1958; Grinstein, Bannerman, and Moore, 1959), it was of interest to examine the distribution of lead inside the cells of liver and kidney homogenates after injection of ${ }^{210} \mathrm{~Pb}$ to rats.

\section{Methods}

\section{Animals}

Forty-six Wistar male rats weighing from 190 to $240 \mathrm{~g}$. were used

\section{Tracer compounds}

${ }^{210} \mathrm{~Pb}$ acetate, specific activity $50 \mathrm{mCi} / \mathrm{mM}$, was obtained from the Radiochemical Centre, Amersham, Bucks. For injection this was diluted with $0.0001 \mathrm{~N}$ acetic acid in $0.9 \% \mathrm{NaCl}$ in water. Radioactivity determinations were carried out employing a well-type crystal scintillation 
counter (Nuclear, Chicago) by estimating the gamma emission of ${ }^{210} \mathrm{~Pb}$.

\section{Treatment of rats}

Injections were given into the femoral vein under ether anaesthesia. Each rat was given $0.2 \mathrm{ml}$. of lead acetate solution, $p \mathrm{H} 4 \cdot 7$, containing $100 \mu \mathrm{g}$. of lead. Radioactivity was $10^{6}$ counts per minute (c.p.m.). The distribution of lead in the intracellular fractions of the liver and kidney was studied in six groups of five rats. The animals were killed at intervals up to nine days after injection. An additional group of 16 rats, killed 24 hours after treatment, was used only to prepare liver and kidney mitochondria.

\section{Analytical methods}

The liver and kidneys were removed, minced thoroughly, and washed several times in cold $0.25 \mathrm{M}$ sucrose, thus eliminating most of the contaminating blood. Since it had been previously shown (Castellino and Aloj, 1964) that the concentration of lead per gram of blood accounted for only 1.23 and $0.03 \%$ of the injected dose at one hour and nine days after injection respectively, perfusion of the organs was considered unnecessary. Separation of intracellular particles was accomplished by the method of Hogeboom, Schneider, and Pallade (1948). Homogenization was carried out on small amounts of tissue in a Potter-Elvehjem homogenizer with a Tefion pestle spinning at 700 r.p.m. Each portion was homogenized for 30 seconds. The homogenate was suspended in $0.25 \mathrm{M}$ sucrose, $6 \mathrm{ml}$./g. fresh weight of tissue. Smears were observed under the phase contrast microscope to ensure that the cells had been broken. By centrifugation at $700 \mathrm{~g}$ for 10 minutes the nuclear fraction was isolated. Mitochondria were sedimented from this supernatant by centrifuging at $21,000 \mathrm{~g}$ for 10 minutes. Finally, the microsomal fraction was isolated at $105,000 \mathrm{~g}$ for 60 minutes. The remaining supernatant will be called the soluble fraction. The nuclear fraction and mitochondria were washed twice with $0.25 \mathrm{M}$ sucrose. Each fraction was weighed and the volumes of washing liquid were measured.

The radioactivity and the protein nitrogen (Gornall, Bardawill, and David, 1949) were determined in the homogenates, in each intracellular fraction, and in the washing liquids. The amount of ${ }^{210} \mathrm{~Pb}$ was expressed in counts per minute (Table 1) while the values shown in the figures are corrected for nitrogen content by the formula:

$$
\frac{\text { c.p.m. } / \mathrm{mg} . \mathrm{N} \text { in fraction }}{\text { c.p.m. } / \mathrm{mg} . \mathrm{N} \text { in the homogenate }} \times 100
$$

In order to study further the removal of the metal from the mitochondrial fraction, liver and kidney mitochondria from 16 rats injected 24 hours previously were prepared as above and divided into four equal parts, one of which was used as a control. The others were washed twice either with $0.25 \mathrm{M}$ sucrose or with ethylenediamine tetra-acetate (E.D.T.A.) or diethylenetriaminopentaacetate (D.P.T.A.) both $0.001 \mathrm{M}$ in $0.25 \mathrm{M}$ sucrose. The radioactivity was determined in the mitochondria and in the washing liquids. In Table 2 the values are reported as percentages of radioactivity present in the unwashed control fraction.

\section{Results}

Intracellular distribution of ${ }^{210} \mathrm{~Pb}$ in liver and kidney homogenates

Table 1 shows the radioactivity of the homogenates and of each fraction at different times. Each result is the mean of five rats. Recoveries ranged from $100 \cdot 2$ to $121.0 \%$ in the liver, and from 106.5 to $117.5 \%$ in the kidneys. In Figs 1 and 2, radioactivities are shown calculated from the formula in the Methods section, i.e., radioactivities relative to the radioactivity of the homogenate on a scale such that 100 indicates equal radioactivity/mg. $\mathrm{N}$.

At all times after injection all fractions contained lead. In the liver (Fig. 1) during the first 24 to 72 hours we observed a decrease of the relative radioactivity in the nuclear fraction and an increase in the mitochondria, indicating different rates of lead removal from these intracellular structures. In contrast, no

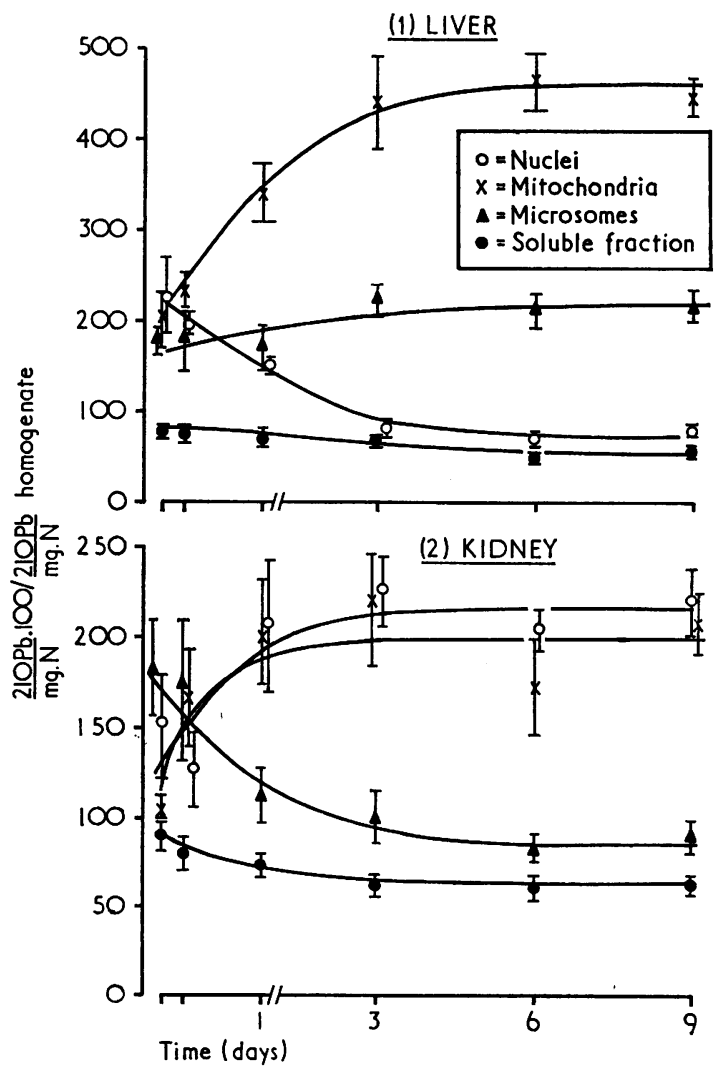

FIG. 1. Distribution of ${ }^{210} \mathrm{~Pb}$ in liver fractions relative to ${ }^{210} \mathrm{~Pb}$ in the whole homogenate corrected for nitrogen content. S.E.M.s are shown.

FIG. 2. Distribution of ${ }^{210} \mathrm{~Pb}$ in kidney fractions; as for Figure 1. 
TABLE 1

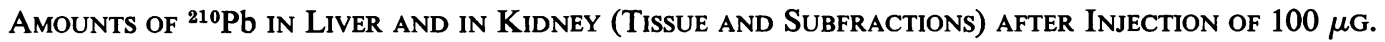

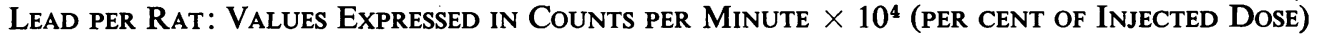

\begin{tabular}{|c|c|c|c|c|c|c|c|c|}
\hline \multirow{2}{*}{$\begin{array}{c}\text { Time } \\
\text { (hours) }\end{array}$} & \multicolumn{8}{|c|}{ Liver } \\
\hline & Homogenate & Nuclei & $\begin{array}{l}\text { Washing } \\
\text { liquid }\end{array}$ & Mitochondria & $\begin{array}{l}\text { Washing } \\
\text { liquid }\end{array}$ & Microsome & $\begin{array}{c}\text { Soluble } \\
\text { fraction }\end{array}$ & $\begin{array}{c}\text { Recovery } \\
\%\end{array}$ \\
\hline $\begin{array}{r}1 \\
6 \\
24 \\
72 \\
144 \\
216\end{array}$ & $\begin{array}{c}17 \cdot 7 \\
13 \cdot 8 \\
7 \cdot 7 \\
3 \cdot 32 \\
1 \cdot 59 \\
0.95\end{array}$ & $\begin{array}{l}5.84 \\
4.28 \\
1.92 \\
0.57 \\
0.25 \\
0 \cdot 15\end{array}$ & $\begin{array}{l}4.72 \\
3.92 \\
1.79 \\
0.55 \\
0.23 \\
0.12\end{array}$ & $\begin{array}{l}1.23 \\
1.14 \\
0.98 \\
0.62 \\
0.30 \\
0 \cdot 19\end{array}$ & $\begin{array}{l}0.24 \\
0.22 \\
0.20 \\
0.13 \\
0.05 \\
0.04\end{array}$ & $\begin{array}{l}3 \cdot 61 \\
2 \cdot 36 \\
1.98 \\
0.99 \\
0 \cdot 48 \\
0.29\end{array}$ & $\begin{array}{l}5 \cdot 76 \\
4 \cdot 24 \\
2 \cdot 08 \\
0 \cdot 87 \\
0 \cdot 32 \\
0 \cdot 21\end{array}$ & $\begin{array}{l}121 \cdot 0 \\
116 \cdot 3 \\
114 \cdot 5 \\
112 \cdot 3 \\
100 \cdot 2 \\
105 \cdot 2\end{array}$ \\
\hline \multirow{2}{*}{$\begin{array}{c}\text { Time } \\
\text { (hours) }\end{array}$} & \multicolumn{8}{|c|}{ Kidney } \\
\hline & Homogenate & Nuclei & $\begin{array}{c}\text { Washing } \\
\text { liquid }\end{array}$ & Mitochondria & $\begin{array}{l}\text { Washing } \\
\text { liquid }\end{array}$ & Microsome & $\begin{array}{c}\text { Soluble } \\
\text { fraction }\end{array}$ & $\begin{array}{c}\text { Recovery } \\
\%\end{array}$ \\
\hline $\begin{array}{r}1 \\
6 \\
24 \\
72 \\
144 \\
216\end{array}$ & $\begin{array}{c}20 \cdot 1 \\
18 \cdot 3 \\
12 \cdot 7 \\
5 \cdot 75 \\
2 \cdot 81 \\
1.64\end{array}$ & $\begin{array}{l}5 \cdot 16 \\
4 \cdot 18 \\
3 \cdot 66 \\
1 \cdot 64 \\
0 \cdot 74 \\
0 \cdot 43\end{array}$ & $\begin{array}{l}5 \cdot 14 \\
4 \cdot 12 \\
3 \cdot 70 \\
1 \cdot 52 \\
0 \cdot 76 \\
0 \cdot 45\end{array}$ & $\begin{array}{l}2 \cdot 41 \\
3 \cdot 42 \\
3 \cdot 40 \\
1 \cdot 51 \\
0 \cdot 68 \\
0 \cdot 37\end{array}$ & $\begin{array}{l}0.48 \\
0.66 \\
0.62 \\
0.31 \\
0.16 \\
0.07\end{array}$ & $\begin{array}{l}3.47 \\
2.88 \\
1.22 \\
0.47 \\
0.18 \\
0.11\end{array}$ & $\begin{array}{l}6 \cdot 12 \\
4 \cdot 88 \\
2 \cdot 31 \\
1 \cdot 14 \\
0 \cdot 47 \\
0 \cdot 34\end{array}$ & $\begin{array}{l}113.0 \\
109.7 \\
117.5 \\
114.6 \\
106.5 \\
107.3\end{array}$ \\
\hline
\end{tabular}

important variations occurred in the relative radioactivities in the microsomes and in the soluble fractions. At later times the relative radioactivities in all intracellular fractions became almost constant, i.e., all lost radioactivity at the same fractional rate as the liver as a whole, indicating the setting up of an equilibrium state.

In the kidney (Fig. 2), during the first 24 hours after injection, we observed increases of the relative radioactivities in the nuclear and the mitochondrial fractions, a decrease in the microsomes, and little change in the soluble fraction. After 24 hours the distribution of lead inside the kidney cells reached an equilibrium state, as indicated by relative radioactivities which remained almost constant up to nine days.

\section{Removal of ${ }^{210} \mathrm{~Pb}$ from mitochondria}

As reported under Methods, during the isolation of fractions the nuclei and mitochondria were washed twice with $0.25 \mathrm{M}$ sucrose. The washings removed about $50 \%$ and $20 \%$ of the radioactivity from the nuclear and mitochondrial fractions respectively.

Mitochondria from the liver and kidneys of 16 rats injected with ${ }^{210} \mathrm{~Pb}$ were washed with sucrose, E.D.T.A., and D.T.P.A. solutions (see under Methods). Table 2 shows that 80.0 to $87.6 \%$ and 80.2 to $86.2 \%$ of radioactivity remained after two washes in liver and in kidney mitochondria respectively. The high proportion of radioactivity which remained bound to the mitochondria after repeated
TABLE 2

Percentage of ${ }^{210} \mathrm{~Pb}$ in the MitochondRial Fractions AFTER WASHING AND IN THE WASHING MEDIA

\begin{tabular}{|c|c|c|c|}
\hline Washing medium & Sample & $\begin{array}{c}\text { Liver } \\
\%\end{array}$ & $\begin{array}{c}\text { Kidney } \\
\%\end{array}$ \\
\hline Sucrose, $0.25 \mathrm{M} \quad \ldots$ & $\begin{array}{l}\text { Mitochondria } \\
\text { First wash } \\
\text { Second wash }\end{array}$ & $\begin{array}{r}82 \cdot 4 \\
20 \cdot 3 \\
4 \cdot 1\end{array}$ & $\begin{array}{r}80 \cdot 2 \\
18 \cdot 4 \\
2 \cdot 1\end{array}$ \\
\hline $\begin{array}{l}\text { E.D.T.A. (mM) in sucrose, } \\
0.25 \mathrm{M}\end{array}$ & $\begin{array}{l}\text { Mitochondria } \\
\text { First wash } \\
\text { Second wash }\end{array}$ & $\begin{array}{r}87 \cdot 6 \\
15 \cdot 3 \\
0 \cdot 0\end{array}$ & $\begin{array}{r}82 \cdot 0 \\
12 \cdot 4 \\
2 \cdot 1\end{array}$ \\
\hline $\begin{array}{l}\text { D.T.P.A. (mM) in sucrose, } \\
0.25 \mathrm{M}\end{array}$ & $\begin{array}{l}\text { Mitochondria } \\
\text { First wash } \\
\text { Second wash }\end{array}$ & $\begin{array}{r}80 \cdot 0 \\
14 \cdot 5 \\
0.0\end{array}$ & $\begin{array}{r}86 \cdot 2 \\
15 \cdot 1 \\
0 \cdot 0\end{array}$ \\
\hline
\end{tabular}

Figures refer to $1 \mathrm{mg}$. of mitochondria or $1 \mathrm{ml}$. of washing medium as percentages of the radioactivity in the unwashed mitrochondrial fraction.

washing shows that the binding was remarkably strong.

\section{Discussion}

Lead poisoning is characterized by a disorder in haemoglobin synthesis, as shown by increases in haem levels and in the urinary excretion of some 
haem precursors (Schmid, Hanson, and Schwartz, 1952; Tishkoff, Granville, Rosen, and Dameshek, 1958; Sano, 1958; Danieli, Gajdos-Török, and Gajdos, 1961; Pecora, Fati, Molé, Balletta, and Daniele, 1963; Crepet and Rubino, 1956; Rubino, 1961).

It is well established that heavy metals can combine with a large variety of organic molecules by interaction with ligands such as sulphydryl, carboxyl, amino, imidazolyl or phosphoryl groups (Passow, Rothstein, and Clarkson, 1961). We think that, because of these interactions, lead may behave as an inhibitor of various enzymes involved in haem biosynthesis. It is therefore interesting that recent studies have established that some important reactions involved in haem biosynthesis take place in the mitochondria - decarboxylation and oxidation of coproporphyrin III to protoporphyrin IX; incorporation of ferrous iron into protoporphyrin IX with formation of haem; and, probably, condensation of $\delta$-aminolaevulinic acid to porphobilinogen (Dresdel, 1955; Sano, 1958; Minakami, Yoneyama, and Yioshikawa, 1958; Eriksen, 1960; Lascelles, 1964; Pilet, 1964; Policard, 1964). The findings reported in this paper show that, within a short time after injection of lead, the metal is incorporated in all intracellular fractions obtained by differential centrifugation of liver and kidney homogenates.

Some variations in the relative amounts of ${ }^{210} \mathrm{~Pb}$ in the intracellular fractions were observed up to 72 hours after injection, indicating different rates of removal of lead from each fraction. These variations rule out any major redistribution of lead in vitro after homogenization, and suggest that the differences in concentration inside the cell probably depend upon the nature and the stability of lead binding to intracellular structures. In both liver and kidneys the ${ }^{210} \mathrm{~Pb}$ present in the mitochondria decreased more slowly than in the other fractions and in the whole homogenate.

From 72 hours to nine days from injection the relative amounts of ${ }^{210} \mathrm{~Pb}$ in the fractions remained constant, suggesting that a steady state had been reached. The slowness with which this equilibrium is reached may depend either upon a strict compartmentation between the different phases in which the lead is distributed inside the cells or upon a slow transformation of the molecular species of the metal in the cell.

The failure to remove ${ }^{210} \mathrm{~Pb}$ from mitochondria by washing suggests that the binding of lead within the mitochondrion is very strong. This seems to be in agreement with the hypothesis of direct interference by lead with some steps in haem biosynthesis (mainly occurring in the mitochondria), probably due to an enzymatic block of $\delta$-aminolaevulinatedehydratase and haem synthetase.

\section{References}

Bernard, H., Gajdos, A., and Gajdos-Török, M. (1958). Biogénèse de l'hémoglobine par le sang périphérique du lapin. Action du plomb du florure de sodium et de l'oxyle de carbone. Expos ann. Biochim. méd., 20, 41-54.

Bolanowska, W., Piotrowski, J., and Trojanowska, B. (1964). The kinetics of distribution and excretion of lead $\left(\mathrm{Pb}^{210}\right)$ in rats. In XIVth int. Congr. occup. Hlth, Madrid 1963, Vol. 2, pp. 420-422. [Exc. med. int. Congr. Ser., No. 62].

Castellino, N., and Aloj, S. (1964). Kinetics of the distribution and excretion of lead in the rat. Brit. J. industr. Med., 21, 308-314.

- (1965). Effects of calcium sodium ethylenediamine-tetraacetate on the kinetics of distribution and excretion of lead in the rat. Ibid., 22, 172-180.

Crepet, M., and Rubino, G. F. (1956). Recenti acquisizioni sul saturnismo. Parte I: Aspetti ematologici della intossicazione. In $X X I$ Nat. Congr. Med. Lavoro. pp. 5-63.

Danieli, G. Gajdos-Török, M., and Gajdos, A. (1961). Un nouveau test biologique du saturnisme: augmentation du taux urinaire et plasmatique de l'acide delta-aminolévulinique. Path. et Biol., 9, 1481-1486.

Dresel, E. I. B. (1955). The rôle of some porphyrins and porphyrinprecursors in the biosynthesis of haem. In Ciba Foundation Symposium on Porphyrin Biosynthesis and Metabolism. pp. 72-85. Churchill, London.

_, and Falk, J. E. (1956). Studies on the biosynthesis of blood pigments. 3. Haem and porphyrin formation from $\delta$-aminolaevulinic acid and from porphobilinogen in haemolysed chicken erythrocytes. Biochem. J., 63, 80-87.

Eriksen, L. (1955). Lead intoxication: 1 the effect of lead on the in vitro biosynthesis of haeme and free erythrocyte porphyrins. Scand J. clin. Lab. Invest, 7, 80-85.

(1960). The rôle of protoporphyrin, iron and globin in haemoglobin formation, and the possible fate of excess in formed protoporphyrin. Les maladies du métabolisme des porphyrines. $2^{\circ}$ Congr. int. Biol. Saclay, pp. 217-234. Presses Universitaires, France.

Gajdos, A., and Gajdos-Török, M. (1958). Anémie hypochrome, hypersidérémique expérimentale par intoxication saturnine, fluorée ou oxycarbonée du lapin. Mécanisme pathogénique. Sang., 29, 444-460.

Goldberg, A., Ashenbrucker, H., Cartwright, G. E., and Wintrobe, M. M. (1956). Studies on the biosynthesis of heme in vitro by avian erythrocytes. Blood, 11, 821-833.

Gornall, A. G., Bardawill, C. J., and David, M. M. (1949). Determination of serum proteins by means of the biuret reaction. J. biol. Chem., 177, 751-766.

Grinstein, M., Bannerman, R. M., and Moore, C. V. (1959). The utilization of protoporphyrin 9 in heme synthesis. Blood, 14, 476-485.

Hogeboom, G. H., Schneider, W. C., and Pallade, G. E. (1948). Cytochemical studies of mammalian tissues. I. Isolation of intact mitochondria from rat liver; some biochemical properties of mitochondria and submicroscopic particulate material. J. biol. Chem., 172, 619-635.

Lascelles, J. (1964). Tetrapyrrole Biosynthesis and its Regulation. Benjamin, New York.

Miani, N., and Viterbo, B. (1958). Studio istoautoradiografico sulla localizzazione del piombo ( $R a D)$ in vari organi di cane. $Z$. Zellforsch., 49, 188-208.

Minakami, S., Yoneyama, Y., and Yoshikawa, H. (1958). On the biosynthesis of heme and hemeproteins in liver cell. Biochim. biophys. Acta (Amst.), 28, 447-449.

Passow, H., Rothstein, A., and Clarkson, T. W. (1961). The general pharmacology of the heavy metals. Pharmacol. Rev., 13, 185-224.

Pecora, L. Fati, S., Molé, R., Balletta A., and Daniele, E. (1963). Il comportamento del metabolismo porfirinico nel saturnismo con particolare riguardo all'ALA e al PBG. Folia med., (Napoli), 46, 107-124.

Pilet, P. E. (1964). La Cellule. Masson, Paris.

Policard, A. (1964). Cellules Vivantes et Population Cellulaires. Structure et Fonctions. Masson, Paris.

Rimington, C. (1951). Preliminary investigations for a study of energy utilized by the surviving fowl erythrocyte in haem synthesis. In Ciba Foundation Conference on $\mu$ Isotopes in Biochemistry, ed. G. E. W. Wolstenholme, pp. 86-89. Churchill, London.

Rubino, G. F. (1961). The rôle of lead in porphyrin metabolism. In Panmin. Med., Symposium on the Normal and Pathological Metabolism of Porphyrin, pp. 40-44.

Sano, S. (1958). The effect of mithocondria on porphyrin and haeme biosynthesis in red blood cells. Acta haemat. jap., 21, 337-349. (Suppl. 2). 
Schmid, R., Hanson, B., and Schwartz, S. (1952). Experimental porphyria. I: isolation of uroporphyrin I from bone marrow of lead poisoned rabbits. Proc. Soc. exp. Biol. (N.Y.), 79, 459-462
Tishkoff, G. H., Granville, N. B., Rosen, R., and Dameshek, W. (1958). Excretion of delta-aminolevulinic acid in lead intoxication. Acta haemat. (Basel), 19, 321-326.

Received for publication May 14, 1968.

\section{The January (1969) Issue}

The occupation of trawl fishing and the medical aid available to the Grimsby deep sea fisherman S. R. W. MOORE

The mortality and morbidity of deep sea fishermen sailing from Grimsby in one year S. R. W. MooRE Absence from work and physical fitness VICTOR LINDÉN

Sleep and wakefulness in a group of shift workers G. S. TUNE

A method for determining the dermal toxicity of pesticides Diana N. Noakes and D. M. SANDERSON

Serum iron and iron kinetics in coalworkers with complicated pneumoconiosis B. W. B. CHAN

Notes and miscellanea

The P4SR index - a critique of a recent criticism R. K. MACPHERSON

Reply to Professor Macpherson's critique C. H. Wyndham, A. McD. Allen, G. A. G. Bredell, and R. ANDREW

Isocyanate hazard from wire insulation: an old hazard in a new guise DeRMOD P. G. PAISLEY

Munchausen's syndrome simulating caisson disease J. H. KEMP and J. G. MUNRO

Book reviews

A number of copies are still available and may be obtained from the Publishing Manager, British Medical Association, Tavistock Square, London W.C.1, price 22s. $6 d$. 